\title{
十二指腸前門脈の 1 成人例
}

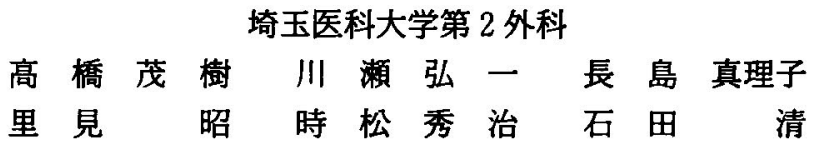

十二指腸前門脈 (PDPV) は胆道閉鎖症との合併例が多く報告されている．しかし，成 人例の報告は少ない. 今回, 成人 1 例を経験したので, 本邦報告例 12 例を集計し, 発生, 治療等に関して考察を加えた。症例は20歳女. 湢吐で発症。手術時, 腸回転異常症と PDPV の合併がわかり，Ladd の手術と十二指腸・十二指腸側々吻合術を行った. 術後は 約 1 年間，ときどき嘔吐がみられたが，その後は順調である. PDPV は成人期になって からでも, 消化管運動の変化, 門脈血流の増加, 内臟下垂などで通過障害を起こす可能 性があると思われた．また，発生に関しては橋本らの説が有力であるが，一元的な説明 は困難である. 手術は十二指腸にある程度通過性のある症例では bypass 術とともに本 来の流れの遮断が必要と思われた。 さらに, 成人外科でも門脈損傷の防止や, 癌との合 併例でのリンパ節郭清の問題など，PDPV の知識が必要であると考えた。

索引用語：十二指腸前門脈, 腸回転異常症

はじめに

十二指腸前門脈 (Preduodenal Portal Vein, 以下 PDPV と略記する）は，小児外科領域では胆道閉鎤症 との合併例が多く報告されている。しかしながら，成 人例の報告は少なく，また，他の疾患の手術中に偶然 に発見されるため，術中に，その取り扱いに苦慮する 例が多い.今回われわれは, 腸回転異常症の診断で手 術し, 術中に腸回転異常症と PDPV の合併であるとわ かった成人の症例を経験したので，本邦報告例を集計 し，発生，治療等に関して考察を加えた。

\section{症例}

患者：20歳，女.

家族歴：特記すべき事項なし。

既往歴：僧帽弁閉銷不全症 ( 4 墄).

現病歴：1984年 4 月専門学校に入学 (19歳) 後, 嘔 吐と下疮が頻回となり，保存的に治療したが改善がみ られないため, 当院消化器内科に入院して精密検查を 行った，検查の結果，十二指腸の狭窄と腸回転異常症 (90度回転) と診断され, 1985年 3 月当科入院となった。

理学的所見：特記すべき事項なし.

血浓学的所見：特記すべき事項なし。

1993年 8 月25日受付 1994年 5 月24日採用
上部消化管造影所見（図 1)：拡張した十二指腸球部 より，わずかに造影郕が流出しており，十二指腸に著 しい狭窄がある(右側)．1 時間後に再度透視を行った ところ狭窄部を通過した造影棛が腹部の右側に貯留し ており，注腸の所見と合わせ 90 度回転の腸回転異常症 と診断した(左側).

手術所見：Ladd 靱帯の圧迫による狭窄と考え手術 を行った．開腹すると十二指腸の前面を膜様物が覆つ

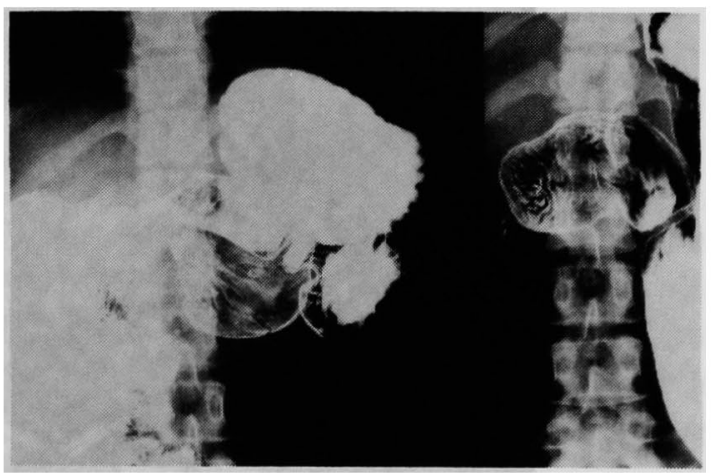

图 1 上部消化管造影

右：㹡張した十二指腸球部と，その先の強い狭䆣をみ とめた，左：1時間後，狭察部を通過した造影剤か腹 部右側にみられた。 


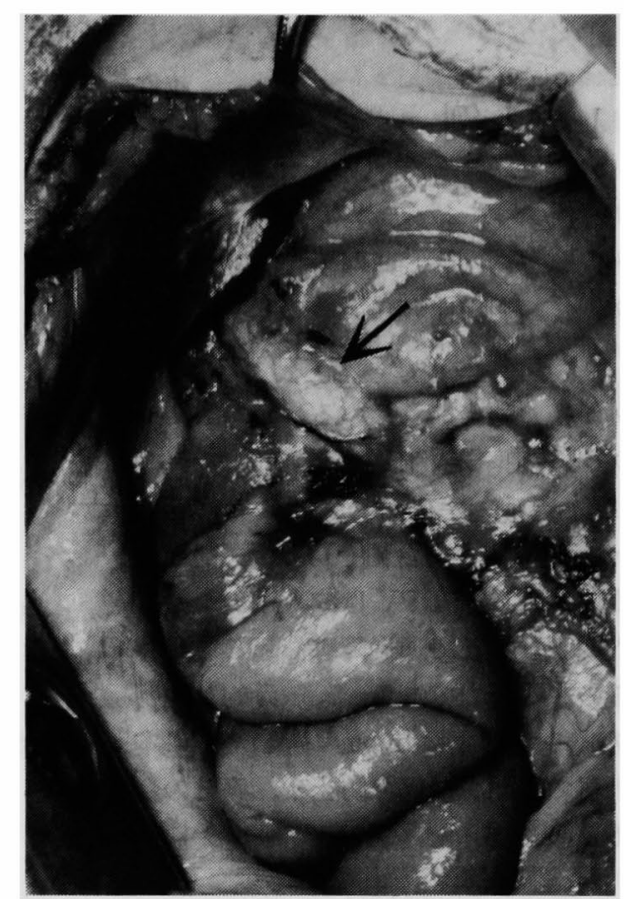

図 2 手術所見：拡張した十二指腸球部と，その右側 前面にある門脈 $(\rightarrow)$ をみとめた。

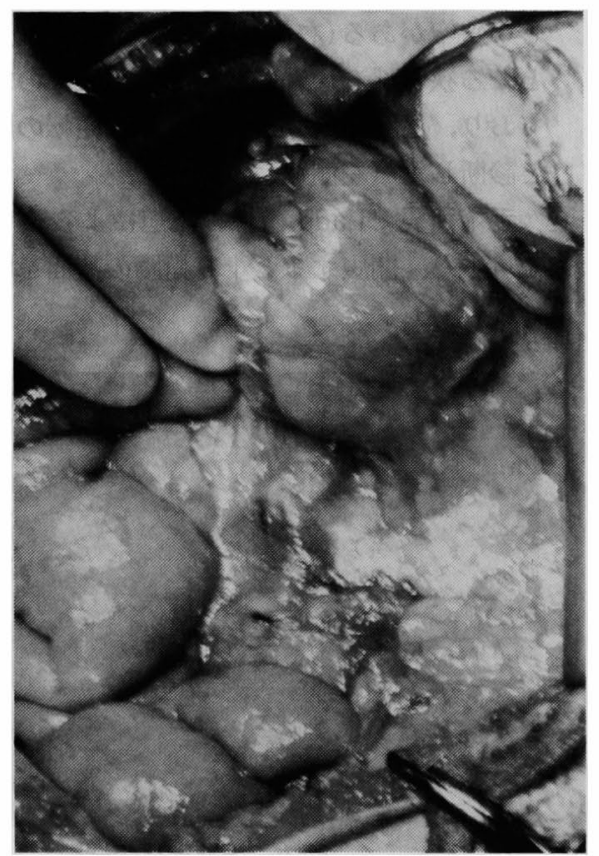

ておりこれを処理すると十二指腸が簬出して，その 前壁をまたぐ門脈を認めた９0度回転の腸回転異常症 はみられたが, Ladd 勒带による圧迫はなく，また，腸 軸捻転も見られず，その他に輪状膵など狭寉の原因に なると考えられるものも認められなかった(図 2). 以 上より PDPV が十二指腸狭窄の原因と考え,門脈が压 迫されないよう注意しながら十二指腸・十二指腸側々 吻合術（ダイヤモンド吻合術）を行った。吻合口は約 $5 \mathrm{~cm}$ とした（図 3 )。 。二指腸を切開したとき内部を観 察したが，膜様狭窄は認められなかった。

術後経過：術後は順調に経過したが, 術後 1 週間で 行った造影検査では吻合部の通過が悪かったので, 胃 カテーテルからの胃夜流出量が減少するのを待って, 術後 2 週より経口摂取を開始した.しかし，嘔吐を絽 り返し，点滴を中止するまで約 1 カ月を要した。その 後も, 約 1 年にわたり体調不良時に何回か嘔吐がみら れた。 1 年経過したころより，ようやく順調となり， 術後 4 年の現在は特に問題なく日常生活を送ってい る.

本邦の成人 PDPV 報告例（表 1 ）：われわれの調べ 得た報告例1) 11) は11例で, 12例目が自験例であった。 年齢分布は 20 ～63歳であり,手術前に PDPV と診断さ
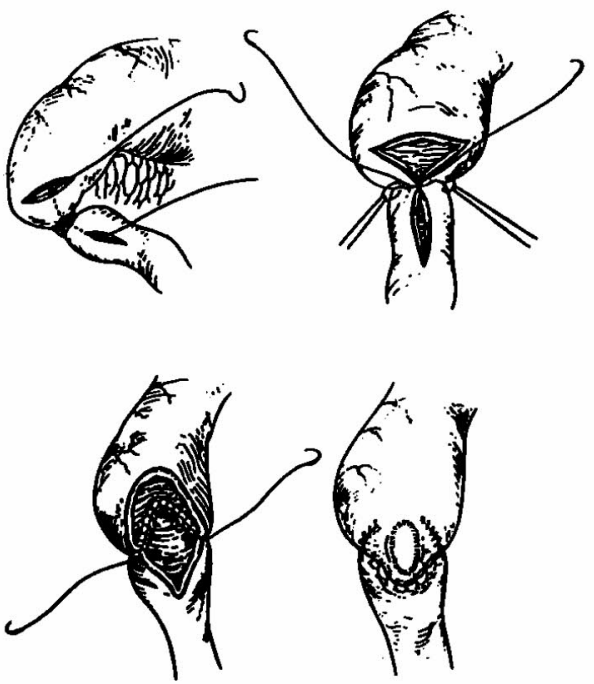

図 3 吻合終了後：吻合はダイヤモンド吻合術で行った.ダィヤモンド吻合術の シェーマを右側にしめす。

(木村ら) 
表 1 十二指䁌前門脈本邦成人報告例

\begin{tabular}{|c|c|c|c|c|c|}
\hline No. & 年龄 & 性 & 術前鉁断 & 合阱奇形 & 術 \\
\hline 1 & 34 & 男 & 胆石应 & なし & 胆票摘除術 - 乳頭形成術 \\
\hline 2 & 33 & 男 & 十二指鹏挾窄 & 棆状㳰 & 胃空腸吻合術 \\
\hline 3 & 20 & 男 & 十二指腸溃的 & 内䑏逆位 & $\begin{array}{l}\text { 選択的迷切 } \\
\text { 空鹃吻合術 }\end{array}$ \\
\hline 4 & 33 & 男 & 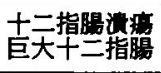 & 十二指腸壁内㽞室 & 鄎室切除術 \\
\hline 5 & 35 & 男 & 縃胆管結石 & $\begin{array}{l}\text { 緦腸間膜症 } \\
\text { 半奇静脈結合 }\end{array}$ & 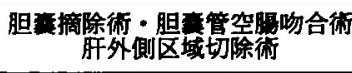 \\
\hline 6 & 53 & 女 & 膵頭部癌 & $\begin{array}{l}\text { 輪状勝・多脾症 } \\
\text { 左側胆设 }\end{array}$ & 膵全摘術 - Roux-en-Y 再建 \\
\hline 7 & 43 & 男 & 早期冒癌 & $\begin{array}{l}\text { 総得間膜症 } \\
\text { メッルル憼室 }\end{array}$ & 胃垔全摘術・B-1再建 \\
\hline 8 & 50 & 男 & $\begin{array}{l}\text { 肝内結石 } \\
\text { 傍乳頭意室 }\end{array}$ & 肝内胆管分岐異常 & 総胆管切開術 - 乳頭形成術 \\
\hline 9 & 34 & 女 & 胃癌 & なし & 周要全摘術 \\
\hline 10 & 45 & 女 & 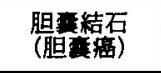 & 半奇静脈結合 & 胆莱摘除術 \\
\hline 11 & 63 & 女 & 胃癌 & なし & 胃垔全摘術・B-1再建 \\
\hline 12 & 20 & 女 & $\begin{array}{l}\text { 十二指腸狭窟 } \\
\text { 腸回転異掌症 }\end{array}$ & $\begin{array}{l}\text { 腸回転異常店 } \\
(90 \text { 蔗回転) }\end{array}$ & ダイヤモンド吻合術 \\
\hline
\end{tabular}

れていた症例は 1 例もない.PDPV が原因で嘔吐がみ られた症例は自験例のみであった. bypass 手術が行わ
れたのは自験例を含め 4 例であったがダイヤモンド吻 合を行ったのはわれわれの症例だけであった。 また,

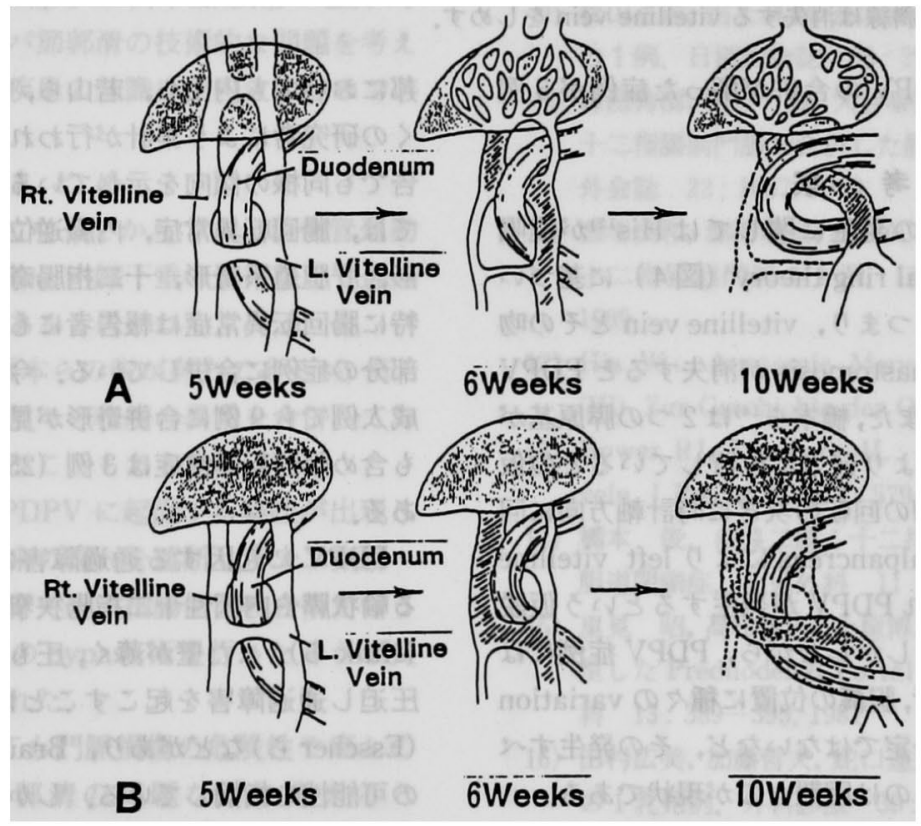

图 4 門脈の発生

A : 正常門脈の発生, B : PDPV の発生（Bower \& Ternberg より）黑斜線は消失し ない vitelline vein (門脈) をしめす. 


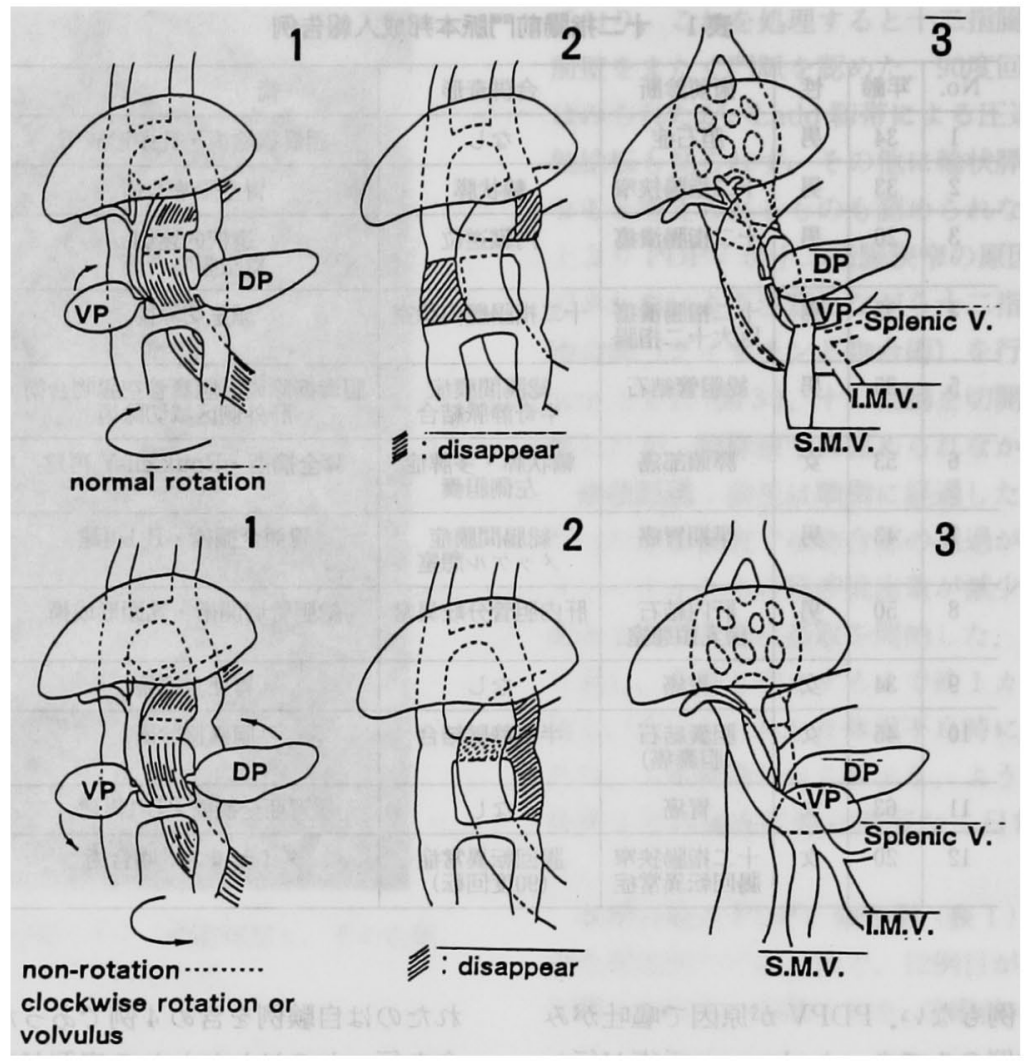

図 5 PDPV の発生(橋本らの仮説)：上段は正常門脈の発生, 下段はPDPV の発生. 黒斜線は消失する vitelline vein をしめす。

悪性腫瘍で手術し PDPV の合併が解った症例が 5 例 あった。

\section{考 察}

一般的にはPDPV の発生に関しては $\mathrm{His}^{12)}$ が提唱 している Periintestinal ring theory（図4）に基づい て説明されている ${ }^{13)}$ 。つまり, vitelline vein とその吻 合枝のうち, dorsal anastomosis が消失すると PDPV ができることになる.また,橋本ら ${ }^{14)}$ は 2 つの膵原基が ともに vitelline veinより前方に位置しているとの仮 定のもとに，腸が最初の回転の次ぎに時計軸方向に回 転したとすると dorsalpancreasにより left vitelline vein の一部が切断され PDPV が発生するという仮説 をたてている(図5)。しかしながら，PDPV 症例には 胆管系や肝動脈の走行, 胆衰の位置に種々の variation があり，膆の形態も一定ではないなど，その発生すべ てを一元的に説明するのは困難なのが現状である.

PDPV は発生時期が胎生 6 週前後と早いため多く の合併奇形が見られる. Braun らは1974年に33例を集 計し，その合併奇形に関して報告している。また，本
邦においても内山ら，若山ら，大久保ら，戸谷など多 くの研究者により集計が行われている゙5)。いずれの報 告でも同様の傾向を示しているが，多い合併奇形とし ては，腸回転異常症，内蔵逆位，心血管系奇形，䏽奇 形, 肝胆道系奇形，十二指腸奇形などがあげられる。 特に腸回転異常症は報告者にもよるが，60〜90\%と大 部分の症例に合併している. 今回われわれが集計した 成人例でも 9 例に合併奇形が見られたが，総腸間膜症 も含め腸回転異常症は 3 例（25\%）にみられたのみで ある。

PDPV に起因する通過障害に関しては合併してい る輪状䐁や内因性十二指腸狭窄が原因であるとする説 （Kalk ら），また壁が薄く，圧も低い閃脈が十二指腸を 圧迫し通過障害を起こすことは考えにくいとする説 (Esscher ら)などがあり，Braun はむしろ門脈圧六進 の可能性を指摘している. しかし，われわれの症例て も他に原因となるものは見られず，小児も含めPDPV

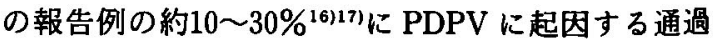
障害がみられていることから考え, PDPV に何らかの 
誘因が加わると喝吐が出現する可能性が大きいと考え られた。成人になってから PDPVに起因すると思われ る喝吐で発症したのは, 本邦ては自験例のみであった。 患者は専門学校入学後に発症しており，環境の変化に よるストレスや，成長に伴う内葴の下垂，門脈血流の 增加などが，その誘因となったものと考えられた。 小児においては，PDPVに起因した嘔吐に対する手 術として，十二指腸・十二指腸側々吻合術または胃・ 十二指腸側々吻合術が良いといわれている。われわれ も十二指腸・十二指腸側々吻合術を行い，しかも吻合 口を大きくしたにもかかわらず，術後の通過状態が悪 く順調に経口摄取できるようになるまで約 1 力月を要 した.ささらに，その後も悪心などの症状が約 1 年間に わたりみられ，もともとの十二指腸の流れが完全に遮 断されていなかったことが，その原因と考えられた。 したがって，成人まで症状が出現しなかった症例では 本来の流れが，ある程度保たれていると考え，その流 れを遮断して側々吻合術を行うか, 完全に離断して他 の bypass 術を行ったほうが良いのではないかと思わ れた，その他，手術時の注意としては側々吻合術によ り十二指腸が門脈を取り巻く形となるため, 門脈圧迫 が起きないよう細心の注意を要することなどが上げら れる.

さらに, 成人の手術に際しても，門脈損傷の危険や， 覀性腫瘍手術時のリンパ節郭清の技術的な問題を考え ると，この小児外科的疾患の知識は不可欠のものであ ると思われた。

\section{まとめ}

1）PDPV は成人期になってからでも, 消化管運動 の変化, 門脈血流の増加, 内臓下垂の進行などで通過 障害を起こす可能性があると思われた。

2）発生に関しては橋本らの説が有力であるが, 肝・ 胆・脺及び十二指腸に種々の程度の異常を合併してお り一元的な説明が困難なこともある。

3）成人になるまでPDPV に起因する嵒吐が出現し なかった症例では，本来の流れを遮断して十二指腸・ 十二指腸側々吻合術, 胃・十二指腸側々吻合術を行う か, 完全に離断して他の bypass 術を行ったほうが良 いのではないかと思われた。

4）成人外科においても門脈損傷の危険性や癌との 合併例でのリンパ節郭清の問題などを考えると PDPV の知識が必要である.

5）成人期発症 PDPV 本邦報告例12例を集計した. なお, 本諭文の要旨は第52回日本臨床外科学会 (1990年11
月14日〜11月16日) ワークショップIV (成人にみられた小児 外科疾患）にて発表した。

\section{文献}

1）大野博通，森岡恭彦，菅原克彦他：脑前面を走行し た門脈異常の 1 例. 日消病会誌 $66: 1392,1969$

2）井坂 晶, 柘植更一：種々の畸形を伴った prepancreatic portal vein $の 1$ 例。日臨外医会誌 $34: 384-385,1973$

3）大久保清一郎, 宮川 皃, 松岡寿夫他：内藏逆位症 および十二指腸謴瘍を伴った Preduodenal Portal Vein の 1 例. 日消外会誌 $11: 310-314,1978$

4) 壬生隆一, 吉富聰一, 後藤庸嘉他：Preduodenal Portal Vein 伴った Intraluminal Duodenal Diverticulum $の 1$ 例. 外科 $43: 1382-1384,1981$

5）松本由朗, 菅原克彦, 井田 健他：門脈走行異常 一臨床的意義とその発生機序に関する考察一．日 消外会誌 $16: 2112-2121,1983$

6）松末 智, 柏原貞夫, 小泉俊三他：十二指腸前門脈 等の多発畸形を合併した膁頭部癌の切除例。日消 外会誌 $16: 1262,1983$

7）浦住幸治郎，遠藤清次，二瓶光博他：十二指腸前門 脈の 1 例. 日消外会誌 $21: 1316-1318,1988$

8）梶田咲美乃，木村泰三，瀧島常雄他：肝内結石症を 伴った preduodenal portal vein $の 1$ 例. 神奈川医 会誌 $15: 53,1988$

9）杉山正彦，国土典宏，高木淳彦他：十二指腸前門脈 の 1 例. 日消病会誌 $86: 299,1989$

10）森屋秀樹, 田中 患, 大谷泰雄他：半奇静脈結合と 十二指腸前門脈を合併した胆蕉癌の一症例．日消 外会誌 $22: 1657,1989$

11）国場良和, 津荷龍生, 松田知已他：胃癌に合併した 十二指腸前門脈の 1 例. 日消外会誌 $22: 1657$, 1989

12) His W: Anatomie Menschliche Embryomen (III). Zur Geschichte der Organe, 1885

13) Bower RJ, Ternberg JL: Preduodenal portal vein. J Pediat Surg 7: 579-584, 1972

14）橋本 俊, 由良二郎：十二指腸前門脈に合併した 胆道閉銷症. 小児外科 $11: 1301-1310,1979$

15）里見 昭, 高松英夫, 土屋博之他：十二指腸閉塞を 呈した Preduodenal Portal Vein の経験。小児外 科 $13: 389-395,1981$

16）田村広美, 加藤哲夫, 蛇口達造他：十二指腸前門脈 の 1 乳児例. 外科診療 $30: 1573-1577,1988$

17）畠井芳穂, 泉田直巳, 遠山喜代子他：湢吐を主訴と した Preduodenal Portal Vein $の 1$ 例. 日小児会 誌 $91: 220,1987$ 


\title{
AN ADULT CASE OF PREDUODENAL PORTAL VEIN
}

\author{
Shigeki TAKAHASHI, Hirokazu KAWASE, Mariko NAGASHIMA, Akira SATOMI, \\ Syuzi TOKIMATSU and Kiyoshi ISHIDA \\ Second Department of Surgery, Saitama Medical School
}

Many cases of preduodenal portal vein (PDPV) in an association with biliary atresia have been reported so far, but reports on PDPV in adults are rarely seen in the literature. This paper describes a recent experience of an adult case, with an analysis of 12 such cases in the Japanese literature in terms of the onset of the disease and treatment.

A 20-year-old woman was admitted to the hospital because of vomiting. Upon operation malrotation of the intestine with PDPV was detected. Ladd's operation and side-to-side anastomosis of the duodenum were carried out. Postoperative course was uneventful except for several episodes of vomiting, which sometimes developed for about one year after the operation. PDPV can cause passage disturbance due to a change in bowel movement, increase in portal blood flow, and visceroptosis. Considering of the onset of the disease, Hashimoto's theory is most convincing, however, it is hard to explain the etiology modistically. When we encounter a patient whose duodenum permits to pass through in some degree, operative procedures might have to include bypass operation and cut off of the original passage. We should have knowledge of PDPV in treating adults surgically in terms of preventing portal injury and lymph node dissection in an association with cancer. 